\title{
DEVELOPMENT OF STUDENTS' COMMUNICATIVE CULTURE VIA ONLINE FOREIGN LANGUAGE INTERACTION
}

\author{
Tatyana Klets \\ Pskov State University, Russian Federation \\ Elena Nikiforova \\ Pskov State University, Russian Federation \\ Nadezhda Presnyakova \\ Pskov State University, Russian Federation \\ Maria Starovoitova \\ Pskov State University, Russian Federation
}

\begin{abstract}
The article focuses on the use of digital technologies in the foreign language learning process and the formation of students' communicative culture via online interaction. The issue discussed in this paper is very urgent because nowadays digital technologies are viewed as a comprehensive means of teaching a foreign language in a higher educational institution. General cultural competency and communicative culture, particularly, are considered as an integrative quality of a specialist concerning his potential for selfrealization in his future career. In this regard, the actual problem is the methodically correct organisation of the educational process for students' cultural development on the basis of digital technologies. The research is aimed at the theoretical substantiation of pedagogical effectiveness of the organization of online training in foreign language communication as a condition for the formation of the communicative culture of undergraduate students as well as the generalization of the results of experimental training. To verify the productivity of digital resources in foreign language training and cultural development of university students the authors conducted a pedagogical experiment using theoretical and empirical methods of scientific research. The results of the experiment proved the effectiveness of online teaching in mastering communicative culture components.
\end{abstract}

Keywords: communicative culture, digital technologies, foreign language training, nonlinguistic students.

\section{Introduction}

Modern tertiary education is aimed not only at training a highly professional specialist but also at developing his personality, unveiling his potential, growing his self-awareness, searching for the ways of his selfrealization. Communicative culture is one of the most important aspects of 
students' self-realisation. The pedagogical community is currently paying special attention to the problem of forming communication culture. Modern requirements for the student's personality presuppose mastering a high level of communicative culture, which allows for effective communication in a multicultural world. The issue is also topical due to the need to create an information-subject environment and to form information literacy as a key competence of a university graduate.

However, we have to admit the fact that the level of communicative culture of the majority of non-linguistic undergraduates leaves much to be desired.

In this regard, the use of Internet services and electronic educational resources, in our opinion, provides an intensification of the language training of students, improves its quality, promotes the involvement of students in foreign language communication in their familiar information environment and contributes to the formation of productive communication skills and information literacy.

The goal of our study is to identify the effectiveness of the organization of online training in foreign language communication as a condition for the formation of the communicative culture of undergraduate students as well as to generalize the experience of integrating information and communication technologies into foreign language teaching of undergraduate students of Pskov State University.

The object of the research is the process of foreign language training of students of non-linguistic areas. The subject of the study is online teaching as a tool for the development of communicative culture of undergraduate students of non-linguistic training areas.

To substantiate the relevance of this research, the theoretical and empirical methods were used. As for theoretical research methods used, an analysis of the scientific and pedagogical literature on the problem, system analysis, and synthesis were used.

Practical realization of using information and communication technologies (ICT) in online foreign language communication was implemented within the framework of the pedagogical experiment. So, the empirical part of the study was to generalize the experience of developing speech skills and culture of communication while integrating ICT into the process of teaching a foreign language, as well as to organize, conduct, process and interpret the results of experimental training using methods of observation, interviewing, testing and analysis of the products of students' speech activity. 


\section{The Theoretical Background}

According to the Federal State Educational Standards (Pravitelstvo RF, 2019), a university graduate has to master a certain number of professional and general cultural competences among which developing the culture of communication is a priority. If the formation of professional competency is in the focus of the training programs in fundamental sciences and subjects of specialization, the task of mastering communicative culture is accomplished first of all by virtue of humanistic education.

Among all the humanities disciplines taught at the university, it is foreign language education that does much to develop communicative culture of a student, the explanation being contained in the significance of communicative aspects of the process.

To identify the essence of the concept of "communicative culture", we analyzed the scientific and pedagogical literature on the research topic. This analysis shows that an impressive body of works has already been formed in the scientific and educational resources, in which scientists from various academic fields are engaged in the study of communication problems: philosophy, psychology, sociology, psycholinguistics, pedagogy. This fact emphasizes the importance and urgency of the problems of developing communicative culture. The modern scientific and pedagogical information field presents various approaches to the interpretation of the concept of "communicative culture": methodical, through world outlook, psychological, sociological, environmental, culture-logical and others approaches (Burton \& Dimbleby, 1990; Klementsova, 2019; Kostikova, Prishvina, Ilyushina, Fedotova, \& Belogurov, 2018).

Content analysis of the definition of "communicative culture" allows us to state that there is no single definition of this term, since this concept has a wide connotation. The most universal, in our opinion, is the definition of communicative culture as one of the components of personality culture, characterized by the presence of 1) a set of knowledge, skills and abilities of verbal communication, the ability to operate with them in a relevant way, using their mental, personal and physical qualities to solve communication problems; 2) systems of norms, values and patterns of behavior adopted in society, which allow the individual to effectively perform the comprehensive tasks of business and intercultural communication. It is this interpretation that we have chosen as the basis for our study.

It should be emphasized that all scientists agree that communicative culture is a part of the basic culture of an individual, ensuring his or her readiness for self-determination in life, the establishment of harmonious relations with the surrounding reality and within him- and herself. It is noted that the problem of the formation of the communicative culture of a graduate of a higher school is 
extremely relevant in connection with the modern requirements for the personality of a future specialist, who should be characterized by the ability to develop their own lines of behavior, while showing such qualities as empathy and tolerance (Klets, Malysheva, Presnyakova, \& Starovoitova, 2020; Riemer, 2007).

A culturally advanced specialist is characterized by such abilities as thinking clearly, building oral or written speech logically, participating in business and professional communication efficiently, i.e. in making presentations, taking part in discussions, defending his or her point of view, reading and translating texts in one of the foreign languages, etc. (Klopf, 2001; Polyakova, 2015).

A wide range of abilities and skills, the formation of which characterizes a highly cultured person, gives rise to the need to find an effective means that will successfully influence the development of students' communicative culture.

The teachers faced the problem of finding effective electronic educational resources, which could be used as tools for the development of communicative culture in the process of foreign language online learning. The task was burdened with the necessity to develop students' communicative culture in a new educational environment of spring and autumn 2020 as they had never experienced the situation of distance learning only.

The analysis of the scientific and methodological literature on the problems of online teaching shows that an impressive body of works has already been formed in the scientific and educational resources in which the authors developed teaching methods for speech activities and culture classes through certain Internet tools and revealed the effectiveness of its use in the educational process (Hogan-Brun, \& Whittle, 1998; Katermina, 2019).

However, based on a study of scientific sources, it was revealed that there is an insufficient number of publications devoted to generalizing the experience of using various digital resources in the system of teaching a foreign language to students of non-language areas of training. In the context of this study, the authors aim to test various educational online platforms and identify their productivity for the development of students' speech skills and communicative culture.

\section{Research Methodology}

Within the framework of this research, the authors created the concept of the communicative culture formation of undergraduate students of non-linguistic areas as a condition for their personal development and improvement of universal cultural competencies. We also described educational computer 
platforms that we used in the distance teaching process to intensify students' speech culture.

The following functions of communicative culture were distinguished: human-creative - familiarizing with language and speech; the transfer of social experience - assimilation of established rules of communication; regulatory training and education; value - the formation of a linguistic picture of the world and value attitudes; sign - language as a sign system. These functions are very relevant while observing the dynamics of students' communicative culture development. We also identified the structural components of students' communicative culture: cognitive, emotional and strong-willed, motivational and behavioral. These characteristics are described by such parameters as qualities, knowledge and skills. These components and their parameters are relevant to the purpose of our study. The above mentioned components and their characteristics are summarized in Table 1.

\section{Table1 Communicative Culture Components}

\begin{tabular}{|c|c|}
\hline $\begin{array}{l}\text { Communicative culture } \\
\text { components }\end{array}$ & Required parameters \\
\hline cognitive & $\begin{array}{l}\text { - knowledge of the rules and regulations of communication; } \\
\text { - knowledge of the characteristics of personality perception in } \\
\text { communication; } \\
\text { - perceptual skills; } \\
\text { - attention, thinking and memory; } \\
\text { - development of speech; }\end{array}$ \\
\hline $\begin{array}{l}\text { emotional and strong- } \\
\text { willed }\end{array}$ & $\begin{array}{l}\text { - ability to emotionally volitional regulation of behavior; } \\
\text { - sense of responsibility; } \\
\text { - empathy and attraction; } \\
\text { - mastering expressive and affective speech means; }\end{array}$ \\
\hline motivational & $\begin{array}{l}\text { - conscious goals of communication; } \\
\text { - formed system of attitudes and value orientations; } \\
\text { - the degree of development of communicative interests and } \\
\text { needs; }\end{array}$ \\
\hline behavioral & $\begin{array}{l}\text { - communication skills; } \\
\text { - conflict-free interactions; } \\
\text { - communication styles (verbal and non-verbal). } \\
\text { - compliance with ethical standards. }\end{array}$ \\
\hline
\end{tabular}

Depending on the degree of formation of the structural components of communicative culture (cognitive, emotional and strong-willed, motivational and behavioral), as we have already noted, we determined the levels of its formation, namely: high, medium and low. 
At the high level the qualities are constantly manifested, the student has perfect knowledge in the field of communication culture, has the necessary skills.

At the average level the qualities are not always observed, the criteria are expressed, but they are limited and insufficiently effective in various activities.

At the low level qualities appear rarely or do not appear; necessary knowledge and skills are lacking.

The effectiveness of the use of online educational platforms and ICT technologies in the process of teaching a foreign language and developing students' communicative culture was identified during the experimental work lasted for two semesters (from March 2020 to January 2021) in the academic environment of Pskov State University. In order to test the hypothesis put forward, we conducted an experimental training that covered 96 undergraduate students of non-linguistic areas of training.

As stated earlier, communicative culture of students was investigated in terms of online interaction during distance English language teaching. The training was organized on the basis of the educational platform Moodle, the platform Zoom for teleconferencing, as well as using Internet services, the linguistic and social environment Speaky, educational sites such as British Council, Easy Place Learning, Ted Talks, Web Quest, etc.

Moodle is considered to be the most widely used e-learning platform in academic institutions of Russia. It is successfully employed by Pskov State University and became one of the basic educational platforms for students to learn since the COVID-19 pandemic in 2020.

The Learning Management System (LMS) Moodle is a platform which lets the teachers create quality online courses, provides support to students and assesses the results of their work. For students, it is a personalized learning environment with a set of learner-centred tools.

Zoom as a cloud platform for audio and video conferencing was used by English teachers in combination with Google classroom and Google documents. As the authors' experience shows, Zoom is a convenient digital tool for study, but the teachers should work hard so that the students do not feel the lack of face-to-face teaching. Here some pair and group activities are described:

1. The teacher sets up session rooms in Zoom and divides students into small groups. Each pair is given a task. While the students are working, the teacher visits each room to control the process.

2. Using Google Drive class folder, the teacher creates documents with tasks and distributes them among the students. The students work with their document in pairs. They can make a plan together, brainstorm the statement or write down answers to the questions. 
The tasks' difficulty depends on the students' level of language. If the students are of intermediate and upper-intermediate levels, they can be offered participation in debates. This is the scheme of online debates: 1. Introducing students to the problem (text in Google doc, Zoom screen presentation with videos and images). 2. Statement of thesis and antithesis. 3. Giving general rules (Google doc). 4. Student's work in session halls, preparing their arguments. 5. Performance of each team. 6. Other groups write opinions in chat while the speakers present their opinions. 7. The results are summarized in the evaluation matrix (Google slides).

It should be noted that we are based on the Bring Your Own Devices (BYOD) concept in teaching foreign languages with ICT. Let us consider this notion in more detail. BYOD is a global concept commonly used to mean permitting employees or students to bring personally owned mobile devices (laptops, netbooks, tablets, smartphones, etc.) to their workplace or educational institution and to use them to access corporate, institutional and other information, applications and services (Boettcher \& Conrad, 2016).

Table 2 Authentic Digital Resources for Practicing IT English

\begin{tabular}{|c|c|c|}
\hline $\begin{array}{l}\text { Type of the } \\
\text { resource }\end{array}$ & Name of the resource & Digital resource \\
\hline \multirow{3}{*}{ Magazines } & Mac Tech & https://www.mactech.com/ \\
\hline & CustomPC & https://custompc.raspberrypi.org/ \\
\hline & eWeek & https://www.eweek.com/ \\
\hline \multirow{3}{*}{ Podcasts } & iOSBytes & https://sur.ly/o/iosbytes.codeschool.com/ \\
\hline & $\begin{array}{c}\text { Android Developers } \\
\text { Backstage }\end{array}$ & https://player.fm/ \\
\hline & Talk Python To Me & https://talkpython.fm/ \\
\hline \multirow[t]{3}{*}{ YouTube channels } & CNET & https://www.youtube.com/user/CNETTV \\
\hline & Linus Tech Tips & $\begin{array}{l}\text { https://www.youtube.com/user/LinusTech } \\
\text { Tip }\end{array}$ \\
\hline & The Verge & https://www.youtube.com/user/TheVerge \\
\hline \multirow{3}{*}{ Blogs } & Top Flight Computers & https://www.topflightpc.com/blog/ \\
\hline & Velocity Micro Blog & https://www.velocitymicro.com/blog/ \\
\hline & Tom's Hardware & https://www.tomshardware.com \\
\hline \multirow[t]{2}{*}{ Forums } & DevShed & https://www.webmasterworld.com/devshed \\
\hline & Stack Overflow & https://stackoverflow.com/ \\
\hline \multirow{3}{*}{ Websites } & TechRepublic & https://www.techrepublic.com/ \\
\hline & ToolBox & https://www.toolbox.com/tech/ \\
\hline & BBC News Tech & https://www.bbc.com/news/technology \\
\hline
\end{tabular}

The students use their mobile devices for doing their homework and working online in Zoom. They are offered a number of applications helpful in 
learning English, links of online monolingual dictionaries and language corpuses. Also, the students are given a range of links with their professional content that they use doing their projects and research, preparing their speeches and presentations.

The given example represents the usage of BYOD techniques within the Bachelor course "English in the Sphere of Professional Communication (Bachelor degree in Information Technologies)" (Table 2).

The instructions are given to students to explain how the BYOD policy is being introduced in class and at home. Let us consider the example of the BYOD-driven lesson layout (Table 3).

\section{Table 3 The BYOD-driven Lesson Layout}

\footnotetext{
Topic: HTML

1. Warming up: Look through Apple official website [https://www.apple.com/] and say what you find useful or needless, attractive or odd.

2. Give the definitions to the terms: HTML, SGML, DOM, HTTP, HTTPS. Use Longman Online Dictionary [https://www.ldoceonline.com/], if necessary.

3. Some basic vocabulary practice (matching/gap-filling): Internet service provider, web browser, web hosting service, domain name, web server capacity, proxy server, malwares, viruses, etc.

4. Group work: Read the article "The best browser 2020" by Carrie Marshal [https://www.techradar.com/best/browser] and put five questions to other groups in class to check students' understanding of the article.

5. Group work: Scan the article "7 simple steps to creating a website" [https://longtailpro.com/7-simple-steps-to-creating-a-website/] and make your own plan of the website you are going to create with your group for a new technology company.

6. Individual homework: follow the link [https://www.w3schools.com/html/default.asp]. Watch HTML tutorial, test yourself with exercises, do HTML Quiz test.

7. Group homework: after expanding your knowledge doing individual homework, continue working on the project you have started in class. Create a website for a customer.
}

It should be noted that digital education gives the teachers an enormous number of techniques and tools but, at the same time, the teacher must work hard to overcome the lack of face-to-face interaction. Online lessons performed on digital platforms help to develop productive speaking activities only if they are well planned and pursue a definite goal.

\section{Research Results}

Let us consider the course of experimental training and analyse its main results in detail. The pedagogical experiment included two stages: 
1) ascertaining and 2) forming. At the ascertaining stage we developed a technology for the formation of communicative culture, which had a four-part structure and included the following components: diagnostic, substantive, technological and reflective. At each of them, the teacher and students performed certain functions. Besides, didactic and methodological possibilities of using ICT technologies as a means of developing students' communicative culture in foreign language classes were identified. At the forming stage the proper online teaching based on digital technologies was performed.

A questionnaire survey on the subject of communicative culture formation was conducted among the students at both stages of the experiment. Testing was carried out using the questionnaire proposed by L.Michelson (Ilyin, 2013). All questions of the questionnaire are divided into several types of communicative situations: situations in which a reaction to positive statements from a partner is required, situations requiring a negative assessment and reaction to it, situations requiring empathy and tolerance, conversation situations, discussions, requests. These groups of questions correlate with the corresponding components of the structure of communicative culture (cognitive, emotional and strong-willed, motivational and behavioral). It should be emphasized that the components of communicative culture are inextricably linked, therefore, elements of various components can interact within the framework of one issue.

At the initial stage of training, the average indicator of the level of communicative culture formation was approximately 51\%. At the final stage of training, based on a questionnaire of students and an expert assessment of teachers, the increase in the four components of communicative culture was, on average, approximately 15 percent (Figure 1 ).

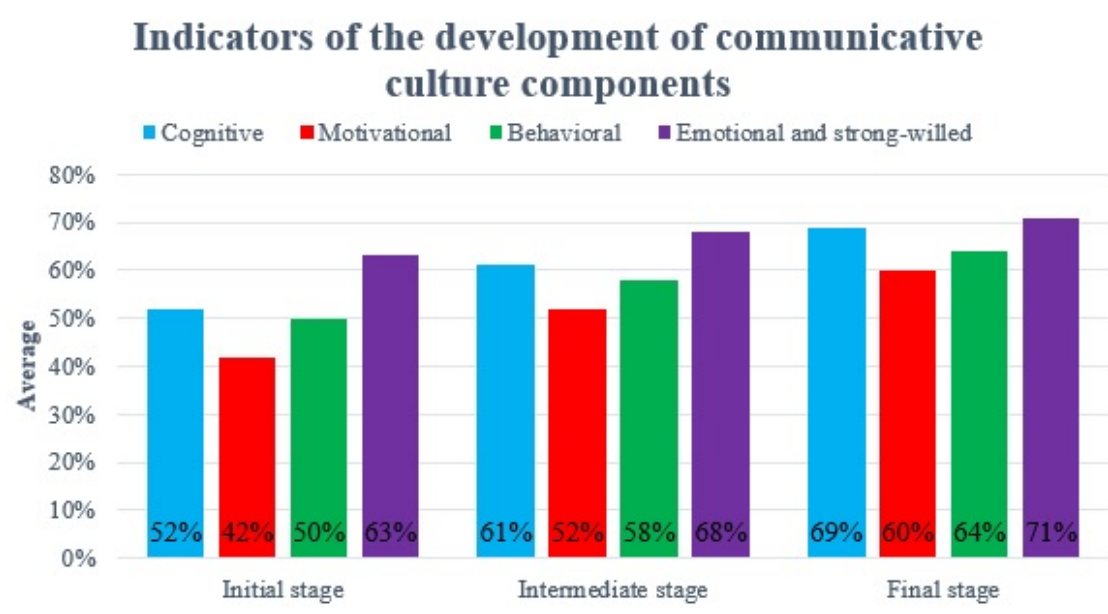

Figure 1 The Results of Evaluating the Development of Communicative Culture Components (based on students' testing) 
Based on the empirical data obtained, we were convinced that in all academic groups there was a transition of the majority of students from low to intermediate and higher levels. On the basis of a reflexive assessment of their speech activity, students identified the prospects for improving communication skills and speech strategies.

In general, there was a positive attitude of students to the used online learning methodology. The data of the conducted pedagogical experiment revealed significant positive speech skills' transformation and confirmed the effectiveness of the use of ICT in language training of non-linguistic students.

As a result, students became more confident, engaged and motivated. They developed their language skills that are the main components of foreign language communicative competence: 1) writing (essays, reports, texting); 2) reading (texts, articles, messages); 3) listening (recordings, podcasts, news); 4) speaking (recording their speeches, giving presentations, filling the gaps in the video with dialogues). The statistical analysis of the experimental data confirmed the correctness of the hypothesis put forward in the study about the effectiveness of online learning in the development of students' communicative culture. Thus, the conducted research allowed to achieve the main objectives.

\section{Conclusion}

Communicative culture is gradually becoming the leading component of the current social transformations in society. The development of communicative culture is an important priority in the professional training of a future specialist who is expected to be able to carry out effective interaction in the process of joint production activities and establish the necessary business, interpersonal and intercultural relations based on cooperation, mutual respect and support.

In the educational practice of higher education, the discipline "Foreign language" has a significant development resource for students' communicative culture, since mastering a foreign language involves a wide and varied use of interdisciplinary connections.

The study undertaken here advocates the effectiveness of online foreign language interaction in developing communicative skills and culture of university students.

Thus, teaching English with the use of infocommunication technologies and multimedia systems had a positive effect on improving the communication culture and contributed to the improvement of the foreign language communicative competence of students as the goal of language training at the university. We can state that online education is ecologically friendly, convenient, enjoyable and modern. 
SOCIETY. INTEGRATION. EDUCATION

Proceedings of the International Scientific Conference. Volume V, May $28^{\text {th }}-29^{\text {th }}, 2021.360-370$

We consider the conducted research to be quite important, since it expands the understanding of the possibilities of online teaching English at a university. The materials of this study can be tested in the practice of teachers in determining the content, means and mechanisms of the formation of the communicative culture of students.

\section{References}

Boettcher, J. \& Conrad, R. (2016). The online teaching survival guide. San Francisco: JosseyBass.

Burton, G., \& Dimbleby, R. (1990). Teaching communication. Routledge: London and New York.

Ilyin, E.P. (2013). Psychology of communication and interpersonal relations: SPb.: Peter.

Pravitelstvo RF. (2019). Federal'nyye gosudarstvennyye obrazovatel'nyye standarty vysshego obrazovaniya po napravleniyam bakalavriata. Retrieved from Федеральные государственные образовательные стандарты высшего образования - Supроrt (fgosvo.ru)

Hogan-Brun, G. \& Whittle, R. (1998). The potential of multimedia for foreign language learning: a critical evaluation. Computers and the Humanities, 31, 451-457.

Katermina, V. (2019). E-learning in the foreign language teaching context. Society. Integration. Education: Proceedings of the International Scientific Conference. Vol. III, 473-478. DOI:10.17770/sie2019vol3.3721

Klementsova, N. (2019). To the technology of forming general cultural competency of a future engineer. The European Proceedings of Social \& Behavioural Sciences. PCSE2019 International Scientific Conference on Professional Culture of the Specialist of the Future. Vol.52, 78-88. DOI:10.15405/epsbs.2019.12.10

Klets, T., Malysheva, O., Presnyakova, N., \& Starovoitova, M. (2020). The development of a bachelor's soft skills through project activities in a foreign language. Society. Integration. Education: Proceedings of the International Scientific Conference. Vol. V, 459-470. DOI:10.17770/sie2019vol3.5010

Klopf, D.W. (2001). Intercultural encounters: the fundamentals of intercultural communication. NY: Morton Publishing Company.

Kostikova, L. P, Prishvina, V. V., Ilyushina, A. V., Fedotova, O. S., \& Belogurov, A. Yu. (2018). Culture in teaching English as a foreign language. Proceedings of the 2018 International Conference on Culture, Education and Financial Development of Modern Society (ICCESE 2018). Advances in Social Science, Education and Humanities Research, 205, 13-17. DOI:10.2991/iccese-18.2018.4

Polyakova, T. (2015). Variety of engineers` needs in the foreign language usage as a basis for their training diversification. Procedia - Social and Behavioral Sciences, 214, 86-94. DOI: 10.1016/j.sbspro.2015.11.598

Riemer, J. M. (2007). Communication Skills for the 21st Century Engineer. Global Journal of Engineering Education, 11 (1), 89-100. 